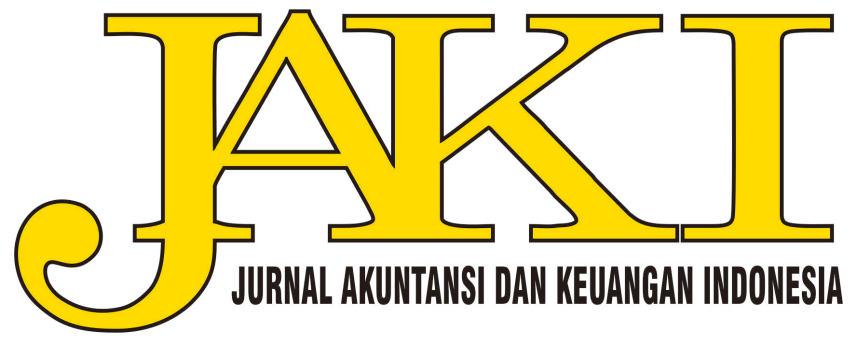

Volume 18

Issue 1 Volume 18, Issue 1, 2021

Article 1

7-31-2021

\title{
THE INFLUENCE OF THE CEO POPULARITY ON PERFORMANCE OF BANKING COMPANIES AT THE EARLIER STAGES OF COVID-19
}

Dian Kusuma Wardhani

Airlangga University

Wiwik Supratiwi

Airlangga University

Follow this and additional works at: https://scholarhub.ui.ac.id/jaki

Part of the Accounting Commons, Corporate Finance Commons, Finance and Financial Management Commons, and the Taxation Commons

\section{Recommended Citation}

Wardhani, Dian Kusuma and Supratiwi, Wiwik (2021) "THE INFLUENCE OF THE CEO POPULARITY ON PERFORMANCE OF BANKING COMPANIES AT THE EARLIER STAGES OF COVID-19," Jurnal Akuntansi dan Keuangan Indonesia: Vol. 18: Iss. 1, Article 1.

DOI: 10.21002/jaki.2021.01

Available at: https://scholarhub.ui.ac.id/jaki/vol18/iss1/1

This Article is brought to you for free and open access by the Faculty of Economics \& Business at UI Scholars Hub. It has been accepted for inclusion in Jurnal Akuntansi dan Keuangan Indonesia by an authorized editor of UI Scholars Hub. 
Jurnal Akuntansi dan Keuangan Indonesia

Volume 18 Issue 1, June 2021

\title{
THE INFLUENCE OF THE CEO POPULARITY ON PERFORMANCE OF BANKING COMPANIES AT THE EARLIER STAGES OF COVID-19
}

\author{
Dian Kusuma Wardhani \\ Airlangga University \\ dian.kusuma.wardhani-2019@feb.unair.ac.id \\ Wiwik Supratiwi \\ Airlangga University \\ wiwik_s@feb.unar.ac.id
}

\begin{abstract}
This study aims to obtain empirical evidence about the influence of CEO popularity on banking performance at the earlier stages of the COVID-19 pandemic in Indonesia. The CEO popularity significantly improve based on their achievements in the public mass media. The study sample consisted of 108 banking companies listed on the Indonesia Stock Exchange in Q1 - Q3 2020. Panel data regression with a common influence model approach was used for analysis, while the company performance was measured using Tobin's $Q$. The result showed that CEO popularity in the banking sector positively affects company performance. Therefore, hiring popular CEO helps obtain better company performance.
\end{abstract}

Keywords: CEO popularity, company performance, CEO characteristics.

\begin{abstract}
Abstrak
Penelitian ini bertujuan untuk mendapatkan bukti empiris tentang pengaruh popularitas CEO terhadap kinerja perusahaan perbankan pada awal pandemi Covid-19 di Indonesia. Popularitas CEO diperoleh dengan intensitas pemberitaan prestasi mereka di media masa publik. Sampel penelitian ini terdiri atas 108 perusahaan perbankan yang terdaftar di Bursa Efek Indonesia untuk periode Q1 - Q3 Tahun 2020. Penelitian ini menggunakan teknik analisis regresi data panel dengan pendekatan common effect model. Kinerja perusahaan diukur menggunakan Tobin's Q. Temuan penelitian ini menunjukkan bahwa popularitas CEO di sektor perbankan berpengaruh positif pada kinerja perusahaan. Oleh karena itu, penelitian ini menunjukkan bahwa mempekerjakan CEO populer merupakan salah satu upaya untuk mendapatkan kinerja perusahaan yang lebih baik.
\end{abstract}

Kata kunci: Popularitas CEO, kinerja perusahaan, karakteristik CEO.

\section{BACKGROUND}

In the current state of information disclosure, individuals in the public spotlight include celebrities or government officials. However, the Chief Executive Officers (CEO) also attract public attention, gaining more popularity. The intensity of the news in the public mass media usually indicate the popularity of the CEO (Love et al. 2017). The public always emphasizes leadership and how they produce high company performance (Lin et al. 2020). Furthermore, the intensity of the public spotlight was higher at the earlier stages of 
the COVID-19 pandemic. This is because the community was more active in observing and responding to all efforts made by the company CEO. It is vital for popular CEO to demonstrate the ability to maintain growth of the company and high performance amid uncertain conditions.

The influence of a CEO popularity on company performance at the earlier stages of the COVID-19 pandemic can be explained by agency theory and the upper echelon. According to agency theory, CEO is motivated to be disciplined and provide potential information to owners when they have high popularity (Gibbons and Murphy 1992; Jensen and Meckling 1992). 1976; Pucheta-Martínez and Gallego-Álvarez 2019). Their efforts to provide relevant details at the earlier stages of the pandemic reduced information asymmetry between owners and managers. This helped minimize agency problems and maintain the popularity (Kaur and Singh 2018).

According to echelon theory, CEO leadership is influenced by personal characteristics that reflect their respective cognitive abilities (Zein et al. 2016). The personal characteristics affect the choice of strategic decisions and the responses to the company's operational problems, which influences the level of performance later (Abatecola and Cristofaro 2018). Upper echelon theory explains that a popular CEO have communication skills and high crisis sensitivity. For this reason, one works comprehensively and carefully while choosing management strategies because the quality and effectiveness of the strategy directly affect the level of company performance and their image before stakeholders (Gamache and McNamara 2019; Hambrick and Mason 1984). To minimize the risk due to the uncertainty of the COVID-19 pandemic, the popular CEO select the best strategy by maximally accommodating all stakeholder interests to maintain the company performance in a positive area to maintain its popularity (Altarawneh et al. 2020; Chatterjee and Hambrick 2007).
The positive influence of the CEO popularity on the company performance at the earlier stages of the COVID-19 pandemic can be shown by the rewards won. For instance, President Director of Bank Rakyat Indonesia (Persero), a public company, won several awards, including the Best CEO in Banking Transformation in Consumer News and Business Channel Indonesia Award 2020, and the CEO Best Talent Development at the 9th Award for State-Owned Enterprises (BUMN) 2020, and Top National Banker 2020 from Investor Magazine (Banjarnahor 2020; Pratama 2020). The awards increased the coverage of Sunarso's leadership in the public mass media and strengthened the positive image of the leadership both at the national and regional Asia Pacific levels (Maulana 2020). In response to the restrictions on activities related to COVID19 , Sunarso took steps to organize and distribute micro-credit through the BRISPOT application. For this reason, the credit distribution process for public companies Bank Rakyat Indonesia (Persero) remained contactless. Non-performing loans of up to Q3 2020 were recorded, 3.12\% lower than the national figure of $3.15 \%$ (Shandy 2020).

Apart from the positive image, Sunarso's popularity positively affected the company performance. In 2020, the company recorded a net profit of $\mathrm{Rp} \mathrm{10,200}$ trillion, higher than the estimated profit of Rp 9,440 trillion. This surge was attributed to the operational adjustment due to COVID-19 conditions (Uly 2020). The positive influence was also shown by the increase in commission-based and other operating income to $\mathrm{Rp} 13.740$ trillion, a growth of $13.4 \%$ (YoY) (Kunjana 2020). Furthermore, Sunarso's popularity as CEO led to increased shares from the beginning of the year to Q3 2020, up 16.25\%. A trade transaction value of Rp. 358.87 billion was also recorded. (Sidik 2020).

The experience of Persero shows that the popularity of CEO is profitable. This is because of the superior management skills and a good sense of crisis. Stakeholders of 
every company responded well to the COVID-19 pandemic are responded well by stakeholders, leading to performance growth amid a pandemic (Lok and Lee 2020). The popularity of CEO increases public awareness regarding the companies they lead, attracting new investors and motivating employees to continue striving to be the best in their industry (Lee et al. 2020). Additionally, the popularity of a CEO also affects their career, business connections, and a large amount of remuneration obtained from company management (Harymawan et al. 2020; Kanapathippillai et al. 2019; Wu et al. 2018).

Popularity opens up opportunities for new job offers, which may eventually lead to multiple positions in other companies (Brown et al. 2019). Because of many management responsibilities, a CEO become very busy with divided attention. Lacking effective strategies may lead to a decline in performance levels, especially during this COVID-19 pandemic (Handschumacher et al. 2019; Saleh et al. 2020). According to the previous study, when the CEO is busy, the corporation performance may decline. The relationship tends to be stronger where the company growth is high, and the CEO tenure is short (Harymawan et al. 2019).

CEOs with high popularity often have strong leadership power that earns them respect from directors (Fang et al. 2020). This power effect affects their expertise in solving problems and the company performance. However, their popularity and excess power may have had a bad effect because of making them arrogant. In general, arrogant popular CEOs feel like rulers and may pressure the directors under them. They often engage in earnings management practices to keep pace with competitors and maintain their popularity in the company's industrial sector (Lin et al. 2020). According to Weng and Chen (2017), CEO popularity does not affect company performance because the company's reputation might be the same irrespective of the popularity.
This study aims to obtain empirical evidence regarding the influence of CEO popularity on company performance in the early days of COVID-19. The sample includes banking companies listed on the Indonesia Stock Exchange (IDX) with an observation period of Q1 - Q3 2020. Banking is chosen because it is a sector that gets strict supervision from the government and financial authorities. Furthermore, the effect of the performance of banking companies is felt faster in the real economy and faster CEO rotation than in other sectors (Altunbaş et al. 2019; Pucheta-Martínez and Gallego-Álvarez 2019). The announcement of the first positive case of COVID-19 on March 2, 2020 (Q1) and the imposition of activity restrictions that affected all company operations, the uncertainty regarding when the pandemic will end, and the continuous decline in the JCI after the first case was revealed influenced the performance of banking companies listed on the IDX (Sugianto 2020). This study focused on the early period of the COVID-19 pandemic in Indonesia because of the challenge the CEO of banking companies faced in maintaining the performance of their respective companies.

The previous study discussed several characteristics of a CEO, such as busyness that negatively affect the company's accounting performance (Harymawan et al. 2019), power, and narcissism which positively affect the accounting performance (Fang et al. 2020; Uppal 2020), and the positive influence of over-confidence on the accounting and market performance of the company (Reyes et al. 2020). The novelty of this study is to examine other characteristics of a CEO, specifically popularity and its effect on company performance. This is an interesting subject because it still receives less attention from researchers, yet it may have positively affected the performance of company performance at the earlier stages of the COVID-19 pandemic. Furthermore, the study contributes to the banking literature by identifying the issues currently in the 
spotlight of the Indonesian community, specifically the popularity of a CEO and the extent to which their leadership affects the performance of the companies they lead during the pandemic.

This study only captures positive news that publishes the achievements or innovations of the CEO of a banking company to optimize the performance at the earlier stages of the COVID-19 pandemic. The findings indicate that the popularity of a CEO has a positive effect because the personal characteristics, such as a sense of crisis and the high prudence principle to maintain their image, lead to a better and more effective quality strategy for maintaining the company performance during the pandemic. These results support Lee et al. (2020) by providing additional evidence on the management practices of banking companies that popular a CEO has a better ability, commitment, and work motivation to produce high performance. During the COVID-19 pandemic, which was full of uncertainty, the performance of the sample companies was well maintained, and the rights of shareholders were still fulfilled. The study also expands knowledge regarding the characteristics of CEO popularity and its effect on company performance, especially in the early days of COVID-19.

\section{LITERATURE REVIEW AND HYPOTHESES FORMULATION}

\section{Agency Theory}

Agency relationship occurs when the owner entrusts the manager (agent) to take some action and delegates decision-making authority to the agent (Jensen and Meckling 1976). This theory holds that high popularity motivates a CEO to be disciplined in their work because of providing potential information to the owner or em-ployer to maintain their popularity (Bai et al. 2019). Openness and delivery of potential accountable information to shareholders are essential, especially during the COVID-19 pandemic. This is because it can minimize agency problems that may arise due to differences in interests between the principal and agent shareholders (Laher 2020).

\section{Upper Echelon Theory}

According to this theory, the performance of an organization is a reflection of the cognitive abilities of the top leadership (Hambrick 2007; Hambrick and Mason 1984). The theory suggests that the CEO leadership is influenced by the breadth of knowledge, beliefs, and characteristics (Kaur and Singh 2018; Saeed and Ziaulhaq 2019). These characteristics shape and determine the way of thinking in making strategic company decisions (Abatecola and Cristofaro 2018). Therefore, it is important to study their characteristics because they the performance of companies and profits (Altarawneh et al. 2020; Chatterjee and Hambrick 2007). In the current era of information disclosure, the popularity influences the choice of strategic decisions and determines company performance. This characteristic is increasingly in the spotlight during the COVID-19 pandemic because of the need to maintain company performance during the pandemic. A popular CEO has a better mana-gerial, communication, and knowledge skills and can read market situations quickly. Therefore, their strategic decisions are of high quality and help maintain and improve company performance during a pandemic (Hambrick 2007; Shahab et al. 2020).

\section{Hypothesis Formulation}

A CEO plays important roles in organizational structure, including to lead and be responsible for all operational activities and performance (Chen and Keefe 2020). Along with the development of human thought, the role of the CEO is interpreted as being a mentor and directing the success of the organization.

Popularity is generally obtained from the intensity of high-frequency reporting of achievements in the public mass media, including television, newspapers, or the internet (Love et al. 2017; Tseng et al. 2017). The intensity of this news was 
higher at the earlier stages of COVID-19 because the public was actively monitoring and responding quickly to all efforts made by the company CEO. According to Lee et al. (2020), the popularity of a CEO is advantageous because public awareness of the company existence improves with their presence in public media. This is in line with Bai et al. (2019), which stated that the good image built from the CEO popularity attracts new investors' attention. Furthermore, the popularity positively affects career, business connections, and large remuneration from the management (Harymawan et al. 2020; Kanapathippillai et al. 2019).

All the positive effects mentioned earlier force popular CEO to deliver better results to maintain their companies' growth and high performance amidst many uncertain conditions due to the impact of the pandemic. Theoretically, agency theory thinking explains that the company management role will be higher when led by a popular CEO. This is because of the motivation to work appropriately because to provide potential information to owners (Jensen and Meckling 1976; Laher 2020). According to the upper echelon theory, a popular value and cognitive characters produce higher quality and effective strategic decisions. This helps maintain the company performance during the COVID19 pandemic (Abatecola and Cristofaro 2018). Based on the views of the two theories, previous study as well as the phenomenon in Bank Rakyat Indonesia (Persero) public companies, the proposed hypothesis is:

\section{$\mathrm{H}_{1}$ : The popularity of the CEO positively affects the company performance at the earlier stages of COVID-19.}

\section{STUDY METHODS}

\section{Data and Sample}

The study sample includes the banking companies listed on the IDX in the first to third quarters (Q1 - Q3) of 2020. The selection of this period was motivated by the announcement of the first positive case of COVID-19 in Indonesia on March 2 2020 (Q1) and the continued decline in the JCI after the first case was revealed to the public (Sugianto 2020). Banking companies were chosen because the impact of their performance is felt more quickly in real economic conditions, faster CEO turnover, and tighter supervision by regulators on banking operations and performance (Altunbaş et al. 2019; Fang et al. 2020). The data was obtained from the published quarterly financial statements on the www.IDX.co.id or the company's website. CEO popularity data was obtained from the sites www.swa.co.id and www.cnbcindonesia.com by looking at the number of CEO reports on the two sites during the observation period. The news captured from the two sites was only positive and related to the CEO's achievements or innovations in creating maximum company performance at the earlier stages of the COVID-19 pandemic. The initial population totaled 138 observations from 46 banking companies listed on the IDX. Companies that do not publish quarterly financial statements were excluded from the sample because they lacked complete data for research needs, leaving 126 observations. Furthermore, observational data with a $\mathrm{z}$-score above 3 or -3 were excluded because they were outliers. A final sample of 108 observations was obtained (Ghozali 2016).

\section{Definition of Operational and Measurement of Variables}

\section{Dependent Variable}

The dependent variable of this study is the company performance measured by Tobin's Q. Since the measurement assesses the company performance in a dynamic market perspective, it is expected to provide good results and reflect the actual performance of banking companies during the COVID-19 pandemic (Lim et al. al. 2019). Tobin's Q measurement refers to PuchetaMartínez and Gallego-Álvarez (2019) by adding up the market capitalization value of 
Table 1

Measurement of Variables

\begin{tabular}{ll}
\hline \multicolumn{1}{c}{ Variable } & \multicolumn{1}{c}{ Method } \\
\hline Firm Performance (FP) & Tobins'Q $=$ (market capitalization value of the company's stock + \\
& total book value of debt) / total book value of assets. \\
Popularitas of the CEO & Number of positive news regarding the company CEO on the \\
(POPULARITY) & www.swa.co.id and www.cnbcindonesia.com pages. \\
Leverage (LEV) & Total debt / total assets. \\
Company Size (FS) & Ln total assets. \\
CEO Tenure (TENURE) & Ln number of days served as CEO of the company. \\
Non-Performing Loan (NPL) & Percentage of total bad loans / total credit. \\
\hline
\end{tabular}

the shares with the total book value of the debt divided by the book value of the total assets.

\section{Independent Variable}

The independent variable is the popularity of the CEO. This is the popularity of a managing director based on the intensity of reporting their achievements in the public mass media (Koh 2011; Love et al. 2017). Its measurement refers to Love et al. (2017) by counting positive news related to the CEO in public mass media pages accessed online through www.swa.co.id and www.cnbcindonesia.com. SWA Magazine, accessed through www.swa.co.id, writes positive news related to the CEO success in producing high performance and actively conducts independent research on the company performance. It regularly holds award events to appreciate outstanding company directors in Indonesia (SWA 2020). CNBC Indonesia actively holds the CNBC Awards as an appreciation for the high performance (CNBC Indonesia 2020). This television channel was chosen because it is the largest and integrated economic media in Indonesia. Since it is also affiliated with CNBC International, it covers the global realm. The two online public mass media were used to obtain positive news regarding the leadership of the CEO in the nationally and globally. This is because of their credibility, which reports and appreciates the performance of business actors independently through a rigorous and comprehensive assessment process.

\section{Control Variable}

Several control variables were used in the study model to avoid bias. The selection of control variables is based on the previous research, including leverage (LEV), company size (FS), CEO tenure (TENURE), and Non-performing loans (NPL) (Bai et al. 2019; Harymawan et al. 2019; Ramlall 2018). LEV is total debt divided by total assets, while FS is the company size indicated by the natural logarithm of its total assets. The TENURE is calculated by the natural logarithm of days served as CEO of the company, while NPL is measured as a percentage of total bad loans compared to total loans. To provide a more specific understanding of the variables, the operationally defined variables are shown in Table 1.

\section{Empirical Model}

This study aims to obtain empirical evidence regarding the effect of the popularity of the CEO on company performance. The analysis technique used the panel data regression method with a common effect model. This method combines cross-sectional and time-series data (Beyaztas and Bandyopadhyay 2020). It increases the degree of freedom, greater data variance, and reducing collinearity between variables to produce efficient econometric estimates (Das 2020; Latimaha et al. 2019). The following regression model was used to test the hypothesis:

$$
\begin{aligned}
F P_{i, t}=\beta_{0}+ & \beta_{1} \text { POPULARITY }_{i, t}+\beta_{2} L E V_{i, t} \\
& +\beta_{3} F S_{i, t}+\beta_{4} \text { TENURE } \\
& +\beta_{5} N P L_{i, t}+\varepsilon_{i, t}
\end{aligned}
$$


Table 2

Descriptive Statistics of Study Sample

\begin{tabular}{rcrrrr}
\hline Variable & N & Min & Max & Mean & Std. Deviation \\
\hline $\begin{array}{c}\text { Dependent Variable } \\
\begin{array}{c}\text { Tobin's Q } \\
\text { Independent Variable }\end{array}\end{array}$ & 108 & 0,001 & 392,182 & 5,719 & 37,950 \\
$\begin{array}{c}\text { POPULARITY } \\
\text { Control Variable }\end{array}$ & 108 & 0,000 & 612,000 & 87,491 & 116,229 \\
LEV & 108 & 0,042 & 0,936 & 0,764 & 0,199 \\
FS & 108 & 26,783 & 37,803 & 31,413 & 2,003 \\
TENURE & 108 & 1,945 & 9,260 & 6,469 & 1,466 \\
NPL & 108 & 0,130 & 5,080 & 2,054 & 1,198 \\
\hline
\end{tabular}

Data source: Processed secondary data

Table 3

Best Model Determination

\begin{tabular}{llllll}
\hline \multicolumn{1}{c}{ Test } & Sig & & Criteria & \multicolumn{1}{c}{ Description } & Conclusion \\
\hline Chow & 0,999 & $>$ & 0,050 & CE is better than FE & Common Effect \\
Hausman & 0,948 & $>$ & 0,050 & RE is better than FE & Random Effect \\
LM & 1,000 & $>$ & 0,050 & CE is better than RE & Common Effect \\
\hline Data source: Processed secondary data
\end{tabular}

Data source: Processed secondary data

where:

$\begin{array}{ll}F P_{i, t} & : \text { firm performance } \\ \beta_{0} & : \text { intercept } \\ \beta_{1,2,3,4,5} & : \text { regression coefficient } \\ \text { POPULARITY } & : \text { CEO popularity } \\ L E V_{i, t} & : \text { leverage } \\ F S_{i, t} & : \text { company size } \\ T E N U R E_{i, t} & : \text { CEO tenure } \\ N P L_{i, t} & : \text { Non-performing loans } \\ \varepsilon_{i, t} & : \text { companu } \\ & \end{array}$

\section{RESULTS AND DISCUSSION}

\section{Descriptive statistics}

Table 2 shows the results of descriptive statistics on the study sample, where the popularity of the CEO has an average value of 87.491. The highest score is owned by Bank BCA Company, meaning that its CEO, Jahja Setiaatmadja, is the most popular in terms of having the highest number of news during the observation period.

The company performance as measured using Tobin's Q based on the results of descriptive statistics has an average value of 5.719 with a standard deviation of 37.950. Herman Halim has the longest CEO tenure of 10419 days and served as CEO of Bank Maspion Company from 1991 until the end of the observation period. Leverage (LEV), company size (FS) and nonperforming loans (NPL) have an average value of $0.764 ; 31,413$ and 2,054 .

\section{Best Model Determination}

This study uses panel data analyzed through three regression approaches, including common effects (CE), fixed effects (FE), and random effects (RE) (Latimaha et al. 2019). The Chow, Hausman, and Lagrange Multiplier (LM) tests were carried out to determine the best model. The results of the three tests are shown in Table 3 by displaying the companys performance measurement using Tobin's Q.

The Chow test has a significance value of 0.999 (significant at the 0.05 level), meaning that the common effects are better than the fixed effects. The significance value of the Hausman test is 0.948 , meaning that the random effects are better than the fixed effects. The significance value of the Lagrange Multiplier Test is 1,000 , meaning that the common effects are better than random effects. Therefore, the common effects approach is used for hypothesis testing. 
Table 4

Multicollinearity Test Results

\begin{tabular}{lc}
\hline \multicolumn{1}{c}{ Variable } & VIF \\
\hline TENURE & 1,100 \\
FS & 1,360 \\
LEV & 1,140 \\
NPL & 1,130 \\
POPULARITY & 1,390 \\
\hline Mean & 1,220 \\
\hline \multicolumn{2}{l}{ Data source: Processed secondary data }
\end{tabular}

Table 5

Pearson Correlation Test Results

\begin{tabular}{lllllll}
\hline \multicolumn{1}{c}{ Variabel } & {$[1]$} & {$[2]$} & {$[3]$} & {$[4]$} & {$[5]$} & {$[6]$} \\
\hline [1] Tobin's $Q$ & 1,000 & & & & & \\
[2] POPULARITY & $0,424^{* * * *}$ & 1,000 & & & & \\
[3] LEV & $-0,022$ & 0,068 & 1,000 & & & \\
[4] FS & 0,100 & $0,485^{* * *}$ & $0,161^{*}$ & 1,000 & & \\
[5] TENURE & 0,063 & 0,024 & $0,273^{* * *}$ & $-0,026$ & 1,000 & \\
[6] NPL & $-0,096$ & - & 0,085 & $-0,190^{* *}$ & $-0,079$ & 1,000 \\
& & $0,299^{* * *}$ & & & &
\end{tabular}

Note: This table shows the results of the Pearson Correlation test. The sample includes 108 banking companies listed on the IDX for the Q1-Q3 year 2020. Signs *, ** and ** are significant at the $10 \%$, $5 \%$ and $1 \%$ levels.

\section{Multicollinearity and Pearson Correlation Tests}

The multicollinearity test was carried out using the variance inflation factor (VIF) test, referring to Lee et al. (2020). Based on Table 4, the VIF of all variables is below the value of 10 , meaning that this study is free from multicollinearity problems.

Table 5 shows the results of the person correlations test. Positive or negative signs indicate the direction and strength of the relationship based on the level of significance. According to this table, the popularity of the CEO is positively related to company performance.

\section{Hypothesis Testing and Discussion}

Table 6 shows the results of the panel regression method hypothesis testing with the common effects model. This study hypothesizes that the popularity of the CEO positively affected company performance at the start of COVID-19. The hypothesis testing showed a significant value at the $1 \%$ level, meaning that the popularity of the CEO significantly affects company performance. The coefficient for the popularity variable is 0.163 , indicating a positive relationship between popularity of the CEO and company performance. This study hypothesis is accepted, meaning that the popularity positively affected company performance at the earlier stages of COVID19. The overall test for the independent variables showed an $R^{2}$ value of 0.200 , meaning that the ability of the independent variable to explain the dependent variable was $20 \%$. Other variables outside of this study influenced the remaining $80 \%$.

This study supports and contributes to the upper echelon theory proposed by Hambrick and Mason (1984) by providing evidence that the popularity of CEO affects 
Table 6

Analysis Results of Common Effect Model Panel Regression

\begin{tabular}{lrrr}
\hline Variabel & \multicolumn{1}{c}{ Coef. } & \multicolumn{1}{c}{ Std. Err } & \multicolumn{1}{c}{ t } \\
\hline Constant & 59,740 & 62,569 & 0,950 \\
POPULARITY & 0,163 & 0,034 & $4,770^{*}$ \\
LEV & $-10,813$ & 17,978 & $-0,600$ \\
FS & $-2,347$ & 1,953 & $-1,200$ \\
TENURE & 1,730 & 2,407 & 0,720 \\
NPL & 1,237 & 2,986 & 0,410 \\
\hline Prob > chi2 & & 0,000 & \\
$\mathrm{R}^{2}$ & & 0,200 & \\
$\mathrm{~N}$ & & 108 & \\
\hline
\end{tabular}

Data source: Processed secondary data

Description: Dependent Variable Tobin's $Q$

Significant at $1 \%$ level

strategic choices, responses, and ways of working. The results strengthen previous research that the popularity of the CEO increases public awareness of the company existence, which attracts new investors and motivates them to work better to produce superior performance (Bai et al. 2019; Kanapathippillai et al. 2019; Lee et al. 2020 ). The popularity is one of the indicators considered by management in the CEO recruitment. This is because the leadership increase stock prices and improved performance.

During the COVID-19 pandemic, the performance of companies with popular CEO was well maintained, hence the rights of shareholders were still fulfilled. The average value of Tobin's $Q$ is 5.719 or greater than one $(>1)$, indicating that the company is valued 5 times greater than the listed company assets. This value also shows that the market gives more value or reacts positively to the company, apart from indicating market confidence in the performance of banking companies during the pandemic.

This study showed that the popularity reflects the ability and quality of the CEO and is not a mere tokenism practice. Popular CEO has high work standards and power in leading management. They always try to provide essential details and maintain information disclosure to maintain a good image, though it is also a form of accountability to stakeholders (Vitanova 2019). In line with the idea of agency theory, openness reduces information asymmetry between management and shareholders to minimize the potential for agency problems because shareholders have high confidence in the management of popular CEO (Laher 2020). From Table 6, all control variables do not affect the performance of banking companies.

\section{Robustness Analysis}

Robustness analysis was conducted to test the performance of the alternative company. Following Cheng et al. (2010), the alternative for measuring company performance used in this study is earnings per share (EPS). This measurement was selected because EPS is one of the performance measurements in accounting (Habibniya and Dsouza 2018). EPS data is obtained from quarterly reports published.

Robustness testing was carried out using a panel data regression model with a random effect approach. The additional test was treated the same as the main model. Therefore, all control variables were also retained in the new regression model. The results of robustness analysis showed that the popularity of the CEO is significant at the $1 \%$ level, meaning that it has a significant effect on company performance as measured by EPS. This influence relationship also indicates a positive direction because the popularity of the CEO 
Table 7

Robustness Analysis

\begin{tabular}{lrrr}
\hline Variabel & \multicolumn{1}{c}{ Coef. } & Std. Err & \multicolumn{1}{c}{ t } \\
\hline Constant & $-365,875$ & 104,325 & $-3,510^{*}$ \\
POPULARITY & 0,478 & 0,061 & $7,770^{*}$ \\
LEV & 22,746 & 31,173 & 0,730 \\
FS & 11,746 & 3,236 & $3,630^{*}$ \\
TENURE & $-0,431$ & 4,256 & $-0,100$ \\
NPL & $-4,614$ & 5,297 & $-0,870$ \\
Mean EPS & 52,913 & & \\
N & 108 & & \\
\hline Data source: Processed secondary data & & \\
Description: Dependent Variable Tobin's $Q$ & & \\
Significant at 1\% level & & &
\end{tabular}

Table 8

Causality Test Results

\begin{tabular}{ccccc}
\hline & Causality & & Wald test & Conclusion \\
\hline POPULARITY & $\longrightarrow$ & Tobin's Q & $0.000^{*}$ & Yes \\
Tobin's Q & POPULARITY & 0.529 & No \\
\hline Data source: Processed secondary data & & &
\end{tabular}

Data source: Processed secondary data

Significant at $1 \%$ level

coefficient has a positive value of 0.478 . The significance value of popularity in the additional analysis is the same as the main model. This means the influence of the popularity of the CEO on company performance as measured by accounting and market perspectives is equally strong.

The EPS ratio describes the stock price of banking companies compared to the profits recorded in the income statement and comprehensive income (Habibniya and Dsouza 2018). EPS has an average value of 52,913 , meaning that the average share of banking companies in the research sample generates a profit of IDR 52,913 per share. A positive value indicates that banking companies with popular CEO during the COVID-19 pandemic still perform well. The good performance is proven based on the calculation of accounting information and market value in the main model by measurement using Tobin's Q. The additional analysis support and strengthen the previous tests and proves that the results of this study are robust.

Furthermore, this study also examined whether there is a causal relationship between company performance and the popularity. Referring to Olaniyi et al. (2017), a Granger causality test was conducted by exploring vector autoregressive (VAR) to determine a causal relationship. From Table 8 , the significance value of Tobin's Q on popularity shows the number 0.529 or $>0.1$, meaning that the company performance does not affect the popularity of the CEO. Also, there is no causal relationship between company performance and popularity of the CEO.

\section{CONCLUSION}

This study aimed to obtain empirical evidence of the effect of the popularity of the CEO on the company performance at the earlier stages of the COVID-19 pandemic in Indonesia. The results show that the popularity positively affects the performance of banking company at the earlier stages of COVID-19. This is in line with Lee et al. (2020), which stated that popular a CEO has a better company management abilities, commitment, and work motivation to produce high performance. During the pandemic, the performance of the company was well maintained, and the rights of shareholders were fulfilled. The popularity of the CEO showed a good 
reputation or image, indicating the quality and ability to lead the management. Therefore, the performance of banking companies remained positive during the early days of the pandemic.

This study implies that the popularity of the CEO in banking is important to improve company performance. The management may use this finding to improve their performance during the pandemic by recruiting popular CEO. Furthermore, this study is beneficial to investors in their investment decision-making. Since the popularity may improve company performance, investors are more interested in investing the funds in banking companies. Moreover, the study supports the development of the upper echelon by proving that the popularity affects strategic choices.

There are some limitations to this study. For instance, using listed banking companies as samples mean the results are limited to the banking literature and cannot be generalized to non-banking companies with different characteristics. Moreover, the research observation time was short because the first positive case of COVID19 was only announced to the public on March 2 2020. The observation time for the impact of COVID-19 was only around six months, hence it did not reflect the situation and impact of the pandemic more clearly and comprehensively.

Further study needs to examine other CEO characteristics that may affect company performance, such as millennial age, gender, and political connections, among others. This study can also be replicated by selecting a research sample of non-banking companies and a longer observation time after announcing the first positive case of COVI-19 to cover data and information better, more clearly, and comprehensively. It expands knowledge of the popularity $\mathrm{CEO}$ and its effect on company performance in earlier stages of COVID-19.

\section{REFERENCES}

Abatecola, G., M. Cristofaro. 2018. Hambrick and Mason's "Upper Echelons Theory": evolution and open avenues. Journal of Management History.

Altarawneh, M., R. Shafie, and R. Ishak. 2020. CEO Characteristics: A Literature Review and Future Directions. Academy of Strategic Management Journal, 19 (1), 1-10.

Altunbaş, Y., J. Thornton, and Y. Uymaz. 2019. The effect of CEO power on bank risk: Do boards and institutional investors matter? ¿s. Finance Research Letters.

Bai, L., X. Yan, and G. Yu. 2019. Impact of CEO media appearance on corporate performance in social media. The North American Journal of Economics and Finance, 50, 100996.

Banjarnahor, D. 2020. BRI Raih BUMN Terbaik \& Sunarso Sebagai Top National Banker. In. Retrieved from https://www.cnbcindonesia.com/new s/20201221005554-4-210430/briraih-bumn-terbaik-sunarso-sebagaitop-national-banker

BEI, Bursa Efek Indonesia. (2020). Mekanisme Perdagangan. Retrieved from

https://www.idx.co.id/investor/meka nisme-perdagangan/

Beyaztas, H. B., and S. Bandyopadhyay. 2020. Robust estimation for linear panel data models. Statistics in Medicine. Statistics in Medicine, 118.

Brown, A. B., J. Dai, and E. Zur. 2019. Too busy or well-connected? Evidence from a shock to multiple directorships. The accounting review, 94 (2), 83-104.

Chatterjee, A., and D. C. Hambrick. 2007. It's all about me: Narcissistic chief executive officers and their effects on company strategy and performance. Administrative science quarterly, 52 (3), 351-386. 
Chen, Z., and M. O. C. Keefe. 2020. Rookie directors and firm performance: Evidence from China. Journal of Corporate Finance, 60, 101511.

Cheng, L. T., Chan, R. Y., \& Leung, T. (2010). Management demography and corporate performance: Evidence from China. International Business Review, 19(3), 261-275.

CNBC Indonesia. (2020). CNBC Indonesia Awards 2020. Retrieved from https://www.cnbcindonesia.com/new s/topik/cnbc-indonesia-award-20202004/all

Das, P. 2020. Panchanan Das: Econometrics in Theory and Practice-Analysis of Cross Section, Time Series and Panel Data with Stata 15.1. In: Springer.

Fang, H., et al. 2020. Effect of CEO power and board strength on bank performance in China. Journal of Asian Economics, 101215.

Gamache, D. L., and G. McNamara. 2019. Responding to bad press: How CEO temporal focus influences the sensitivity to negative media coverage of acquisitions. Academy of management Journal, 62 (3), 918943.

Ghozali, I. 2016. Aplikasi analisis Multivariete dengan program IBM SPSS 23 (edisi 8). Cetakan ke VIII. Semarang: Badan Penerbit Universitas Diponegoro, 96.

Gibbons, R., and K. J. Murphy. 1992. Optimal incentive contracts in the presence of career concerns: Theory and evidence. Journal of political Economy, 100 (3), 468-505.

Habibniya, H., and S. Dsouza. 2018. Impact of performance measurements against market value of shares in Indian banks: An empirical study specific to EVA, EPS, ROA, and ROE. Journal of Management Research, 18 (4), 203-210.

Hambrick, D. C. 2007. Upper echelons theory: An update. In: Academy of
Management Briarcliff Manor, NY 10510.

Hambrick, D. C., and P. A. Mason. 1984. Upper echelons: The organization as a reflection of its top managers. Academy of management review, 9 (2), 193-206.

Handschumacher, F. et al. 2019. Do board interlocks support monitoring effectiveness?

Management Research Review.

Harymawan, I. et al. 2020. Remuneration committees, executive remuneration, and firm performance in Indonesia. Heliyon, 6 (2), e03452.

Harymawan, I. et al. 2019. CEO busyness and firm performance: evidence from Indonesia. Heliyon, 5 (5), e01601.

Jensen, M. C., and W. H. Meckling. 1976. Theory of the firm: Managerial behavior, agency costs and ownership structure. Journal of financial economics, 3 (4), 305-360.

Kanapathippillai, S. et al. 2019. Compensation committees, CEO pay and firm performance. Pacific-Basin Finance Journal, 57, 101187.

Kaur, R., and B. Singh. 2018. CEOs' characteristics and firm performance: a study of Indian firms. Indian Journal of Corporate Governance, 11 (2), 185-200.

Koh, K. 2011. Value or glamour? An empirical investigation of the effect of celebrity CEOs on financial reporting practices and firm performance. Accounting \& Finance, 51(2), 517-547.

Kunjana, G. 2020. BRI Tunjukkan Kinerja Lebih Baik dari Perkiraan. Retrieved from https://investor.id/market-andcorporate/bri-tunjukkan-kinerjalebih-baik-dari-perkiraan

Laher, D. 2020. Conflicting goals in the management of microfinance institutions: an agency theory approach. Enterprise Development and Microfinance, 31 (2), 113-125.

Latimaha, R., Z. Bahari, and N. A. Ismail. 2019. Examining the Linkages 
between Street Crime and Selected State Economic Variables in Malaysia: A Panel Data Analysis. Jurnal Ekonomi Malaysia, 53 (1), 5972.

Lee, G. et al. 2020. Celebrity CEO, identity threat, and impression management: Impact of celebrity status on corporate social responsibility. Journal of Business Research, 111, 69-84.

Lim, K. P., et al. 2019. Women directors and performance: evidence from Malaysia. Equality, Diversity and Inclusion: An International Journal.

Lin, F., S.-W. Lin, and W.-C. Fang. 2020. How CEO narcissism affects earnings management behaviors. The North American Journal of Economics and Finance, 51, 101080.

Lok, C., and K. Lee. 2020. BUSY BOARDS, FIRM PERFORMANCE AND OPERATING RISK. Asian Academy of Management Journal of Accounting \& Finance, 16 (2).

Love, E. G., J. Lim, and M. K. Bednar. 2017. The face of the firm: The influence of CEOs on corporate reputation. Academy of management Journal, 60 (4), 1462-1481.

Maulana, R. 2020. Dirut BRI Sunarso Kembali Torehkan Prestasi sebagai The Best CEO in Banking Transformation. Retrieved from https://www.pikiran-

rakyat.com/nasional/pr-

011103386/dirut-bri-sunarso-

kembali-torehkan-prestasi-sebagai-

the-best-ceo-in-bankingtransformation

Olaniyi, C. O., O. B. Obembe, and E. O. Oni. 2017. Analysis of the nexus between CEO pay and performance of non-financial listed firms in Nigeria. African Development Review, 29 (3), 429-445.

Pratama, A. (2020). Dirut BRI Sunarso Dinobatkan Sebagai Best CEO of The Year. Retrieved from https://www.inews.id/finance/bisnis/ dirut-bri-sunarso-dinobatkansebagai-best-ceo-of-the-year

Pucheta-Martínez, M. C., and I. GallegoÁlvarez. 2019. Do board characteristics drive firm performance? An international perspective. Review of Managerial Science, 1-47.

Ramlall, I. 2018. Ratios/Metrics of Financial Stability Assessment. In Tools and Techniques for Financial Stability Analysis (Vol. 5, pp. 91114): Emerald Publishing Limited.

Reyes, T. et al. 2020. Does overconfidence pay off when things go well? CEO overconfidence, firm performance, and the business cycle. Strategic Organization, 1476127020930659.

Saeed, A., and H. M. Ziaulhaq. 2019. The Impact of CEO Characteristics on the Internationalization of SMEs: Evidence from the UK. Canadian Journal of Administrative Sciences/Revue Canadienne des Sciences de l'Administration, 36(3), 322-335.

Saleh, M. W. et al. 2020. The effect of board multiple directorships and CEO characteristics on firm performance: evidence from Palestine. Journal of Accounting in Emerging Economies.

Shahab, Y., et al. 2020. Chief executive officer attributes, sustainable performance, environmental performance, and environmental reporting: New insights from upper echelons perspective. Business Strategy and the Environment, 29(1), 1-16.

Shandy, K. F. 2020. Manajemen Risiko yang Prudent Bikin Kinerja BRI Positif. Retrieved from https://ekbis.sindonews.com/read/23 6144/178/manajemen-risiko-yangprudent-bikin-kinerja-bri-positif1605661890

Sidik, S. 2020. Wow! Morgan Stanley Borong Saham BBRI Rp 138 M di Pasar Nego. Retrieved from 
https://www.cnbcindonesia.com/mar ket/20201104150514-17-

199268/wow-morgan-stanley-

borong-saham-bbri-rp-138-m-dipasar-nego

Sugianto, D. 2020. Perjalanan IHSG Sejak RI Positif Virus Corona. Diunduh tanggal 24 Juli 2020, https://finance.detik.com/bursa-danvalas/d-4972595/perjalanan-ihsgsejak-ri-positif-virus-corona.

SWA. (2020). About SWA. Retrieved from https://swa.co.id/

Tseng, P.-H., X.-Q, Su, and H.-J. Tsai. 2017. Managerial education and the wealth effect of corporate capital investment in Taiwan. Managerial Finance.

Uly, Y. A. 2020. Semester I-2020, Laba Bersih BRI Menyusut 36,8 Persen. Retrieved from https://money.kompas.com/read/202 0/08/19/120208226/semester-i-2020laba-bersih-bri-menyusut-368persen?page $=$ all

Uppal, N. 2020. CEO narcissism, CEO duality, TMT agreeableness and firm performance. European Business Review.

Vitanova, I. 2019. Nurturing overconfidence: The relationship between leader power, overconfidence and firm performance. The Leadership Quarterly, 101342.

Weng, P.-S., and W.-Y. Chen. 2017. Doing good or choosing well? Corporate reputation, CEO reputation, and corporate financial performance. The North American Journal of Economics and Finance, 39, 223240.

$\mathrm{Wu}, \mathrm{H}$. et al. 2018. Politically connected CEOs, firm performance, and CEO pay. Journal of Business Research, 91, (169-180).

Zein, A., R. Surya, and A. Silfi. 2016. The effect of earnings growth, capital structure, liquidity and independent commissioners on earnings quality with independent commissioners moderated by the competence of independent commissioners: Study on manufacturing companies listed on the Indonesia Stock Exchange in the period 2013-2014. JOM Fekon, 3(1), 980-992. 